\title{
Interaction between Polyoxin and Active Center of Chitin Synthetase ${ }^{\dagger}$
}

\author{
Masahiro Hori,* Kazuo KaKIKI and Tomomasa Misato \\ The Institute of Physical and Chemical Research, Wako-shi, Saitama \\ *Kaken Chemical Co., Ltd., Honkomagome, Bunkyo-ku, Tokyo
}

Received March 16, 1973

\begin{abstract}
Various derivatives of polyoxin $\mathrm{C}$, other polyoxins and several uridine analogues have been known as competitive inhibitors of chitin-UDP acetylglucosaminyltransferase (EC 2.4.1.16, chitin synthetase). Their inhibitory activities were more or less dependent on $\mathrm{pH}$. The variation of inhibitor constants $K i$ or Michaelis-Menten parameters $K m$ and $V$ with pH was investigated and the data obtained were plotted according to the method proposed by Dixon $e t$ al. From the results of the $\mathrm{p} K i$ - $\mathrm{pH}$ plots for the above competitive inhibitors, it was concluded that the ionized amino group at $\mathrm{C}-2$ " position acted a very important role for the binding of polyoxins to chitin synthetase. The carbonyl oxygen atoms at $\mathrm{C}-1$ " and of the carbamoyloxy group probably participated in the hydrogen bond formation with the enzyme. And $\mathrm{pH}$ scarcely influenced on the interaction between the carboxyl group at $\mathrm{C}-\mathrm{5}^{\prime}$ and the enzyme. The results of the Dixon plots for variations of $K m$ and $V$ with pH suggested that an un-ionized imidazole group $\left(\mathrm{p} K_{\mathrm{a}}=6.3\right)$ and an ionized amino group $\left(\mathrm{p} K_{\mathrm{a}}=7.7\right)$ of chitin synthetase were concerned in the enzyme reaction.
\end{abstract}

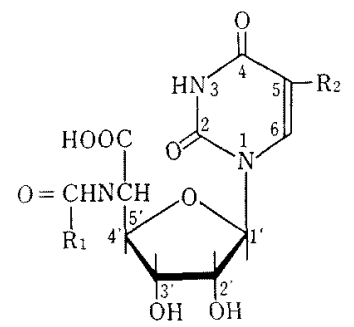

SCHEME 1.

\begin{tabular}{|c|c|c|}
\hline & $\mathrm{R}_{1}$ & $\mathrm{R}_{2}$ \\
\hline $\mathrm{N}$-Acetyl-PoC ${ }^{a}$ & $-\mathrm{CH}_{3}$ & $-\mathrm{CH}_{2} \mathrm{OH}$ \\
\hline Glycyl-PoC & $-\mathrm{CH}_{2}\left(\mathrm{NH}_{2}\right)$ & $-\mathrm{CH}_{2} \mathrm{OH}$ \\
\hline Glycyl-TPoC ${ }^{a}$ & $-\mathrm{CH}_{2}\left(\mathrm{NH}_{2}\right)$ & $-\mathrm{CH}_{3}$ \\
\hline L-Alanyl-TPoC & $-\mathrm{CH}\left(\mathrm{NH}_{2}\right) \mathrm{CH}_{3}$ & $-\mathrm{CH}_{3}$ \\
\hline L-Norvalyl-TPoC & $-\mathrm{CH}\left(\mathrm{NH}_{2}\right) \mathrm{CH}_{2} \mathrm{CH}_{2} \mathrm{CH}_{3}$ & $-\mathrm{CH}_{3}$ \\
\hline$\delta$-CAO ${ }^{a}$-DL-norvalyl-TPoC & $-\mathrm{CH}\left(\mathrm{NH}_{2}\right) \mathrm{CH}_{2} \mathrm{CH}_{2} \mathrm{CH}_{2} \mathrm{OCONH}_{2}$ & $-\mathrm{CH}_{3}$ \\
\hline Polyoxin L & $-\mathrm{CH}\left(\mathrm{NH}_{2}\right) \mathrm{CH}(\mathrm{OH}) \mathrm{CH}(\mathrm{OH}) \mathrm{CH}_{2} \mathrm{OCONH}_{2}$ & $-\mathrm{H}$ \\
\hline Polyoxin M & $-\mathrm{CH}\left(\mathrm{NH}_{2}\right) \mathrm{CH}_{2} \mathrm{CH}(\mathrm{OH}) \mathrm{CH}_{2} \mathrm{OCONH}_{2}$ & $-\mathrm{H}$ \\
\hline
\end{tabular}

a) The abbreviations used are: $\mathrm{PoC}$, polyoxin $\mathrm{C}$; TPoC, thymine-polyoxin $\mathrm{C}$; $\mathrm{CAO}$, carbamoyloxy.

In our previous papers ${ }^{1,2}$ the relation of polyoxin structure to chitin synthetase inhibition has been studied in detail by the kinetic investigation using polyoxins and their

$\dagger$ Studies on the Mode of Action of Polyoxins. Part V. Preceding paper in this series is Ref. 2). analogues, which inhibit the enzyme in competition with the substrate uridine 5 '-diphosphate N-acetylglucosamine (UDP-GlcNAc). From the results obtained, it has been concluded that the carbamoyl polyoxamic acid moeity*1

*1 See Scheme 1 and Ref. 3). 
$\left(-\mathrm{C}(\mathrm{O}) \mathrm{CH}\left(\mathrm{NH}_{2}\right) \mathrm{CH}(\mathrm{OH}) \mathrm{CH}(\mathrm{OH}) \mathrm{CH}_{2} \mathrm{OC}(\mathrm{O})\right.$ $\mathrm{NH}_{2}$ ) of polyoxins helps to stabilize the polyoxin-enzyme complex by the contributions of its $-\mathrm{C}(\mathrm{O}) \mathrm{CH}-$ group $\left(-\Delta g^{* 1}=0.5\right), \quad-\mathrm{NH}_{2}$ group $(-J g=1.3)$ at $\mathrm{C}-2^{\prime \prime}$, aliphatic carbon chain $(-J g=1.0),-\mathrm{OH}$ groups $(-\Delta g=0.9)$ at $\mathrm{C}-3^{\prime \prime}$ and $\mathrm{C}-4$ ", and terminal $-\mathrm{OC}(\mathrm{O}) \mathrm{NH}_{2}$ group $(-\Delta g=0.4)$. Further, it has been inferred that a specific binding site, to which the uridine moiety of UDP-GlcNAc is bound, lies on the enzyme, and that the pyrimidine nucleoside moiety of polyoxins also fits into this binding site.

It has been reported in the preceding paper ${ }^{2}$ that the $K i$ values for polyoxins vary with $\mathrm{pH}$. The investigation on variation of inhibition with $\mathrm{pH}$ has been frequently used as a mean for interpretation of action of inhibitors. When an enzymic reaction is carried out in a limited range of $\mathrm{pH}$ in which the enzyme protein is stable, the relationship between $\mathrm{pH}$ and reaction velocity often shows a bell shaped profile. And from the theory proposed by Dixon and Webb $^{4}$ this result is possible to explain as that specific dissociation groups are contained in the enzyme and the reaction can proceed only in a characteristic state of ionization of these groups. The two proton model for above explanation is summarized in Scheme 2. Where $K e_{1}$ and $K e_{2}$ represent dissociation constants for two groups of a free enzyme HE, and $\mathrm{Kes}_{1}$ and Kes represent dissociation constants for these groups of an enzyme-substrate complex HES. For determining $\mathrm{pKe}$ and $\mathrm{pKes}$ values, Dixon et al. ${ }^{*}$ have described a simple graphical method in which $\mathrm{pH}$ is plotted against $\mathrm{pKm}$ $(=-\log K m), \log V$ or $\log (V / K m)$. By substituting $\mathrm{p} K i(=-\log K i)$ for $\mathrm{p} K m$, the theory discribed above is applicable to interpret the action of inhibitors.

In the present paper, the results of such a kinetic study using particulate chitin synthetase preparation from Piricularia oryzae and its competitive inhibitors are described, and the

*1 Partial binding affinity $\left(\mathrm{kcal} / \mathrm{mole}, 25^{\circ} \mathrm{C}\right)$ has been used to express the contributions of some atoms and atomic groups of polyoxins to the polyoxinenzyme interaction. See Ref. 2).

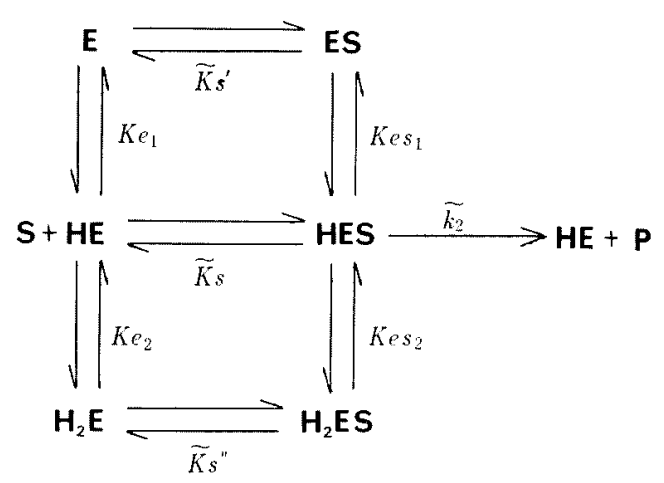

SCHEME 2.

interaction between the active center of the enzyme and the inhibitor polyoxin or the substrate UDP-GlcNAc is discussed.

\section{MATERIALS AND METHODS}

N-Acetyl-PoC, ${ }^{* 2}{ }^{3)}$ glycyl-PoC, ${ }^{5 !}$ glycyl-TPoC, ${ }^{* 2}{ }^{5 !}$ Lalanyl-TPoC, ${ }^{5}$ L-norvalyl-TPoC, ${ }^{5 ;} \delta$-CAO*2 -DL-norvalyl-TPoC, ${ }^{5}$ methyl-PoC ${ }^{* 3}$ and polyoxin $\mathrm{J}^{3}$ ) were generous gifts from Dr. K. Isono, the Institute of Physical and Chemical Research. Polyoxins A, ${ }^{31} \mathrm{~B},{ }^{3}$ $\mathrm{D},{ }^{3 /} \mathrm{L},{ }^{3 /} \mathrm{M},{ }^{6 /}$ polyoxin $\mathrm{C}$ acid ${ }^{3 /}$ and uracil-polyoxin $\mathrm{C}^{31}$ were generously given by Dr. K. Shibuya, Kaken Chemical Co., Ltd. Other chemicals used and preparation of particulate chitin synthetase from $P$. oryzae $\mathrm{P}_{2}$ have been described in the preceding paper. ${ }^{2}$ The enzyme fraction obtained was suspended in $1.5 \mathrm{ml}$ of ice cold distilled water and used for experiments immediately. The protein content was about $20 \mathrm{mg}$ per milliliter. The incubation mixture, for assay of the enzyme activity, contained UDP-GlcNAc- ${ }^{-14} \mathrm{C}$ $(24,000 \mathrm{dpm})$ at a concentration $7.2 \sim 0.7 \mathrm{mM}, 20 \mathrm{~mm}$ $\mathrm{N}$-acetylglucosamine, $3.2 \mathrm{mM} \mathrm{MgCl}, 0.7 \mathrm{~mm}$ mercaptoethanol, $10 \mu 1$ of the enzyme solution and $60 \mu \mathrm{l}$ of $0.05 \mathrm{M}$ Tris-malate- $\mathrm{NaOH}$ buffer with a wide range of $\mathrm{pH}$ in a total volume of $100 \mu \mathrm{l}$. Incubation was carried out for $10 \mathrm{~min}$ at $25^{\circ} \mathrm{C}$ and radioactive chitin formed was separated and counted as described previously. ${ }^{2}$ Michaelis-Menten parameters $K m$ and $V$, and inhibitor constant $K i$ were determined by plotting $1 / \mathrm{v}$ (m $\mu$ moles/ $10 \mathrm{~min}, 25^{\circ} \mathrm{C}$ ) against $1 / \mathrm{S}$ (mM UDP-GlcNAc). ${ }^{7 !}$

\section{RESULTS}

\section{Effect of $\mathrm{pH}$ on chitin synthetase}

The effects of $\mathrm{pH}$ on the enzyme activity

*2 The abbreviations used are: $\mathrm{PoC}$, polyoxin $\mathrm{C}$; TPoC, thymine-polyoxin C; CAO, carbamoyloxy.

*3 Methyl ester of the carboxyl group at $\mathrm{C}-5^{\prime}$ of polyoxin C. Unpublished work by Dr. K. Isono. 
and on the enzyme stability were investigated over the $\mathrm{pH}$ range from 5.2 to 8.6 (Fig. 1). The enzyme activity as a function of $\mathrm{pH}$ gave a bell-shaped curve and showed the optimum $\mathrm{pH}$ at 7.0. The $\mathrm{pH}$ range from 6.0 to 8.6 , in which the enzyme was found to be stable, was used in the following experiments.
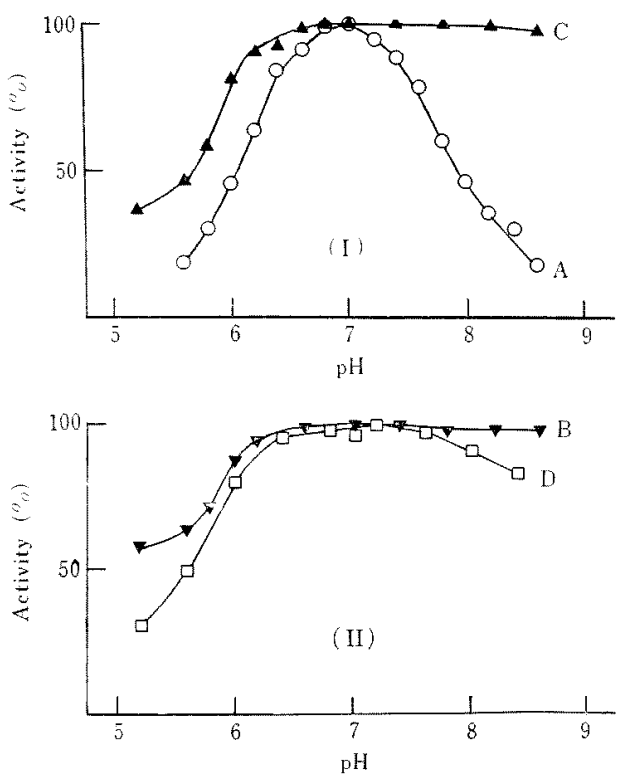

FlG. 1. Effect of $\mathrm{pH}$ on Chitin Synthetase.

For curve A the enzyme activity was assayed for 10 min at $\mathrm{pH}$ values given; for curves $\mathrm{B}, \mathrm{C}$ and $\mathrm{D}$ the enzyme was exposed for $5 \mathrm{~min}, 10 \mathrm{~min}$ and $15 \mathrm{~min}$, respectively, to $\mathrm{pH}$ values given and the residual activity then tested at $\mathrm{pH} 7.2$. Other conditions for the assay of the activity were the same as described in the text except UDP-GlcNAc concentration was $2.6 \mathrm{~mm}$

\section{pH dependence of $\mathrm{Km}$ and $\mathrm{V}$}

The Michaelis-Menten parameters $K m$ and $V$ were determined over the $\mathrm{pH}$ range $6.0 \sim 8.6$. The values of $\mathrm{p} K \mathrm{Km}, \log V$ and $\log (V / \mathrm{Km})$ were calculated from these values and they were plotted against $\mathrm{pH}$ according to Dixon et al. . $^{\text {? }}$ (Fig. 2). Both $\log V$ and $\log (V / K m)$ as a function of $\mathrm{pH}$ showed bell-shaped profiles. As indicated in Fig. 2, the values of $\mathrm{pKe} e_{1}$ $(=6.3), \mathrm{pKe} e_{2}(=7.7), \mathrm{pKes}_{1}(=6.0)$ and $\mathrm{p} K e S_{2}$ $(=8.0)$ were determined according to the graphical method of Dixon et al."

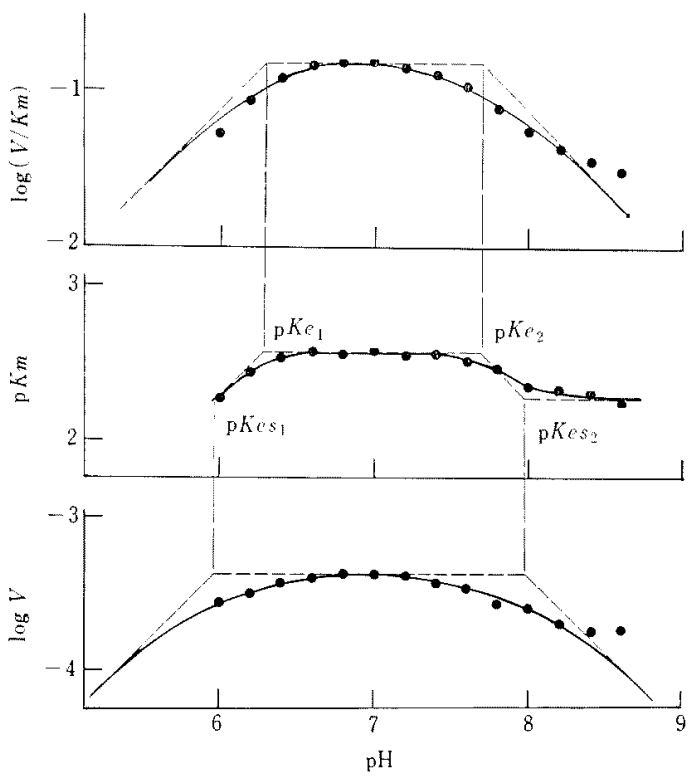

FIG. 2. Effect of $\mathrm{pH}$ on $K m$ and $V$ for Chitin Synthetase.

The experiment using UDP-GlcNAc as the substrate was carried out as described in the text. The values of $\mathrm{Km}$ and of $V$ obtained were plotted according to Dixon and Webb."

Effect of $p H$ on inhibitions of chitin synthetase by competitive inhibitors

The inhibitory activities of various competitive inhibitors of chitin synthetase as a function of $\mathrm{pH}$ were investigated and the results shown in Figs. 3 and 4 were obtained. As Fig. 3 showed, maximum inhibition by polyoxins $\mathrm{B}$, $\mathrm{D}, \mathrm{J}$ and $\mathrm{L}$ occurred at $\mathrm{pH} 6.8$, and above it there was a rapid fall in inhibitory activity. In the case of four N-aminoacyl derivatives of thymine-polyoxin $\mathrm{C}$, the activities were almost constant over $\mathrm{pH}$ range $6.0 \sim 7.6$ and showed a gradual decrease from $\mathrm{pH}$ 8.0. The $\mathrm{pH}$ dependence of the activity of uracil-polyoxin $\mathrm{C}$ and of methyl-polyoxin $\mathrm{C}$ was very small. $\mathrm{N}$-Acetyl-PoC gave the sigmoid $\mathrm{pH}$ profile which has bends at $\mathrm{pH} 7.2$ and 8.0. As shown in Fig. 4, the $\mathrm{pH}$ profiles for uridine and $d$ thymidine apparently differed from those for UMP, UDP and UDP-glucose. The effect of $\mathrm{pH}$ on the activity of the former was very small, while the latter was remarkably affected by $\mathrm{pH}$. 

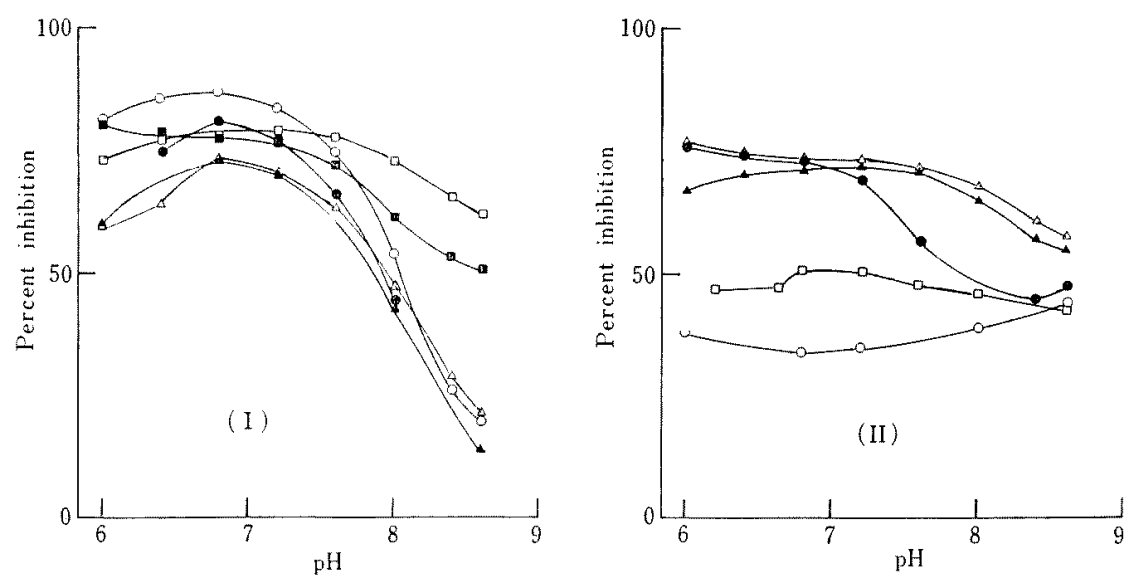

Frg. 3. Effect of $\mathrm{pH}$ on Chitin Synthetase Inhibition by Polyoxins.

The experiment was carried out as described in the text except that the reaction mixture contained $2.6 \mathrm{mM}$ UDP-GIcNAc and the following compounds at concentrations indicated.

(I).

- - polyoxin B $10 \mu \mathrm{M} ; \triangle-\triangle$, polyoxin D $10 \mu \mathrm{M} ; \mathrm{O}-\mathrm{O}$, polyoxin $\mathrm{J} 10 \mu \mathrm{M} ; \boldsymbol{\Lambda}-\mathbf{A}$, polyoxin L $10 \mu \mathrm{M} ;-\hat{\delta}$-CAO-DL-norvalyl-TPoC $125 \mu \mathrm{M} ; \square-\square$, L-norvalyl-TPoC $125 \mu \mathrm{M}$.

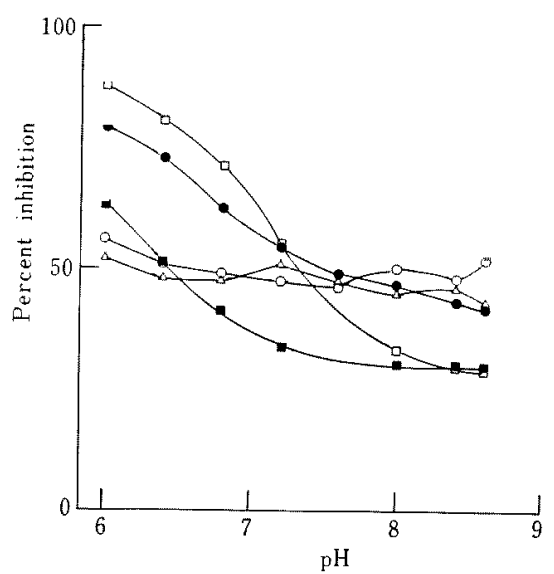

FIG. 4. Effect of $\mathrm{pH}$ on Chitin Synthetase Inhibition by Uridine Compounds and $d$ Thymidine.

The experiment was carried out as described in Fig. 3. $\triangle-\triangle$, uridine $3 \mathrm{~mm}$; - UMP $3 \mathrm{~mm} ; \square-\square$, UDP $3 \mathrm{~mm} ;-$ UDP-glucose $5 \mathrm{~mm} ; \mathrm{O}-\mathrm{O}, d$ thymidine $10 \mathrm{~mm}$.

$\mathrm{pH}$ dependence of $\mathrm{Ki}$ for competitive inhibitors of chitin synthetase

As described above, the inhibitions by several competitive inhibitors were remarkably affected by $\mathrm{pH}$, in contrast the effect of $\mathrm{pH}$ on the inhibitions by some other competitive inhibitors was small over $\mathrm{pH}$ range given. On the
(II).

$\bigcirc-\mathrm{O}$, uracil-polyoxin C $3.5 \mathrm{~mm} ; \square-\square$, methylPoC $3 \mathrm{~mm}$; - N-acetyl-PoC $2.5 \mathrm{~mm} ; \triangle-$ $\triangle$, glycyl-TPoC $625 \mu \mathrm{M} ; \mathbf{A}-\mathbf{A}$, L-alanyl-TPoC $250 \mu \mathrm{M}$.

basis of these results, polyoxins $\mathrm{L}$ and $\mathrm{M}$, L-norvalyl-TPoC, glycyl-PoC, N-acetyl-PoC, methyl-PoC, uracil-PoC, uridine and UMP were chosen and inhibitions of the enzyme by them were investigated as a function of UDPGlcNAc concentration at various $\mathrm{pH}$ values. The data obtained were plotted according to Lineweaver-Burk. $^{7}$ ) These plots showed that they inhibited the enzyme competitively at all $\mathrm{pH}$ values tested. The $K i$ values for the inhibitors at each $\mathrm{pH}$ were determined and from these values the $\mathrm{p} K i$ values were calculated and plotted against $\mathrm{pH}$ according to Dixon et al. ${ }^{4)}$ (Figs. 5 and 6). The $\mathrm{pH}$ profiles of inhibitory activity and $\mathrm{p} K i$ for an inhibitor were similar each other.

As shown in Fig. 5, the pKi for polyoxins $\mathrm{L}$ and $\mathrm{M}$ were found to be approximately independent of $\mathrm{pH}$ over $\mathrm{pH}$ range $6.0 \sim 7.2$ and $6.0 \sim 7.4$, respectively, and then above them there were rapid falls in $\mathrm{p} K i$ values. The $\mathrm{p} K i-\mathrm{pH}$ curves for the former and the latter had bends at pH 7.2 and 7.4, respectively. Glycyl-PoC and L-norvalyl-TPoC gave quite similar curves each other, which were roughly parallel to the axis of abcissa over $\mathrm{pH}$ range 


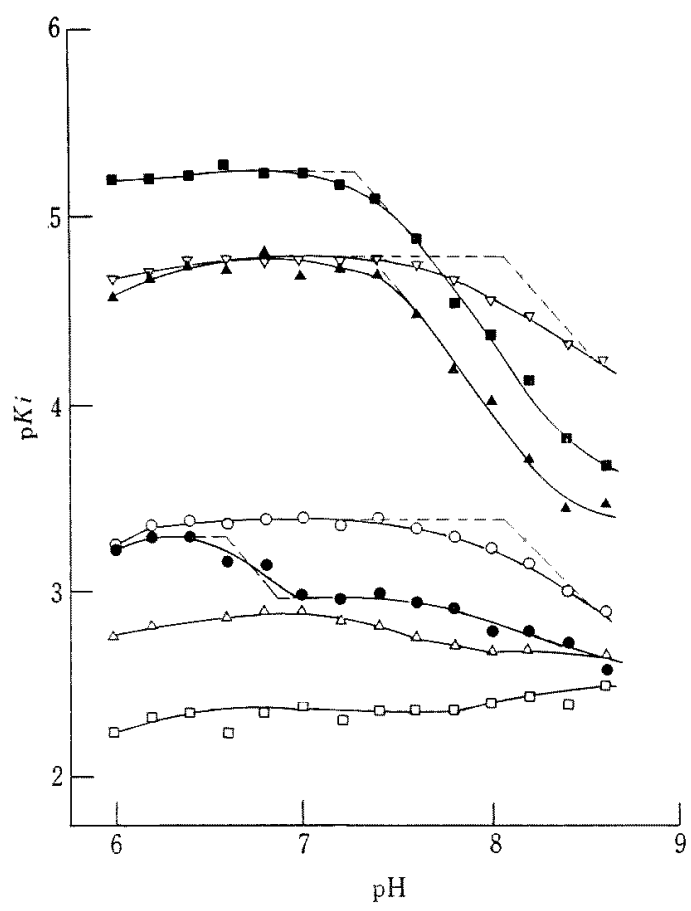

FIG. 5. Effect of $\mathrm{pH}$ on $K i$ Values for Uracil Polyoxin C, Polyoxins L, M and Derivatives of Polyoxin C.

The experiment was carried out as described in the text and the $K i$ values obtained were plotted against $\mathrm{pH}$ according to Dixon and Webb. ${ }^{4}$

$\mathbf{- 1}$, polyoxin $\mathrm{L} ; \mathbf{A}-\mathbf{A}$, polyoxin $\mathrm{M} ; \nabla-\nabla$, norvalyl TPoC; $\mathrm{O}-\mathrm{O}$, glycyl-PoC; $\longrightarrow$, N-acetyl-PoC; $\triangle-\triangle$, methyl-PoC; $\square-\square$, uracil-polyoxin $C$.

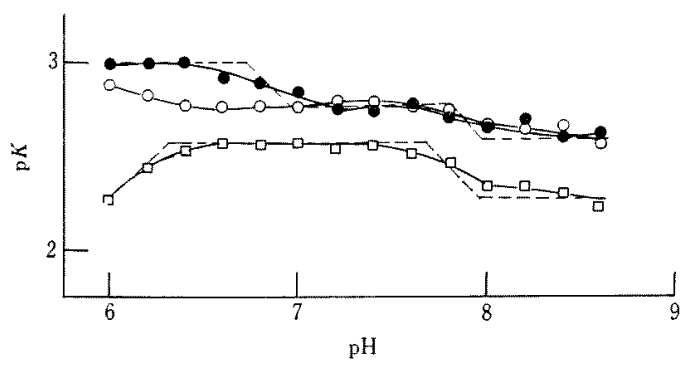

FIG. 6. Effect of $\mathrm{pH}$ on $K i$ Values for Uridine and UMP.

$K i$ for uridine and UMP and $K m$ for UDP-GlcNAc* are expressed as $K$. $\mathrm{O}-\mathrm{O}$, uridine; - - , UMP; $\square-\square$, UDP-GlcNAc.

* The $\mathrm{p} K m$-pH curve obtained in Fig. 6. is shown here again.

$6.0 \sim 7.6$ and showed bends at $\mathrm{pH} 8.0$. However, the $\mathrm{p} K i$ value for the latter was larger than that for the former by about one unit at all $\mathrm{pH}$ values investigated. N-Acetyl-PoC gave the characteristic $\mathrm{pH}$ profile in comparison with its analogues, glycyl-PoC, methyl$\mathrm{PoC}$ and uracil-polyoxin C. The $\mathrm{pKi}$-pH curve for N-acetyl-PoC showed bends at $\mathrm{pH} 6.6$ and 6.9. The $\mathrm{p} K i$ for this compound was approximately the same as that for glycyl-PoC over $\mathrm{pH}$ range $6.0 \sim 6.4$, then it decreased as $\mathrm{pH}$ increased and above $\mathrm{pH} 7.0$ it became roughly close to that for methyl-PoC. The $\mathrm{pK} i$ values for uracil-polyoxin $\mathrm{C}$ and methylPoC were slightly affected by $\mathrm{pH}$. In Fig. 6, it was found that the $\mathrm{p} K i$ - $\mathrm{pH}$ profiles for uridine and UMP have some similarities between the $\mathrm{pKm}$-pH profile for UDP-GlcNAc over $\mathrm{pH}$ range $7.2 \sim 8.6$. Below $\mathrm{pH} 7.0$, the $\mathrm{pK} i$ for UMP was larger by $0.1 \sim 0.3$ unit than that for uridine and showed a downward curvature at $\mathrm{pH} 6.7$.

\section{DISCUSSION}

The results obtained from the $\mathrm{p} K i-\mathrm{pH}$ profiles for uracil-polyoxin $\mathrm{C}$, methyl-polyoxin $\mathrm{C}$ and $\mathrm{N}$-acetyl-PoC indicate that the ionized carboxyl group at $\mathrm{C}-5^{\prime}$ influences little on the $\mathrm{pH}$ behaviour of $\mathrm{N}$-acetyl-PoC, however that the acetyl group of this compound causes the two bends at $\mathrm{pH} 6.6$ and 6.9 on its $\mathrm{pKi}$-pH curve. Therefore, it is presumed that the carbonyl oxygen atom of the acetyl group forms a hydrogen bonding with a positively charged group of the enzyme (e.g., the imidazole group of a histidine residue).

It has been described previously ${ }^{1,2}$ that the amino group at $\mathrm{C}-2^{\prime \prime}$ position of polyoxins is very important group for the polyoxin-enzyme interaction. The $\mathrm{p} K_{\mathrm{a}}$ values of the amino groups of polyoxins $\mathrm{L}$ and $\mathrm{M}$ have been reported to be $7.0^{3)}$ and $7.4{ }^{6)}$ respectively. The results obtained in this paper have indicated that the $\mathrm{p} K i$ - $\mathrm{pH}$ profiles for polyoxins $\mathrm{L}$ and $\mathrm{M}$ have the bends at $\mathrm{pH} 7.2$ and 7.4, respectively, and above these $\mathrm{pH}$ values their inhibitory activities decrease rapidly. Each of the $\mathrm{pH}$ values of the bends approximately corresponds to the $\mathrm{p} K_{\mathrm{a}}$ of the amino group of above polyoxins. Therefore it is possible to say that 
the bends observed in the $\mathrm{p} K i-\mathrm{pH}$ profiles must arise from disappearance of the positive charge of the amino groups at $\mathrm{C}-2$ " of the polyoxins. Although the $\mathrm{pH}$ value $(=8.0)$ of the bends found on the $\mathrm{p} K i$-pH curves for glycyl-PoC and L-norvalyl-TPoC is somewhat larger than those $\mathrm{pH}$ values found in the cases of polyoxins $\mathrm{L}$ and $\mathrm{M}$, these bends may also result from the change in electrical charge of their amino groups at $\mathrm{C}-2^{\prime \prime}$ When discussion here is confined to $\mathrm{p} K_{\mathrm{a}}$ of an amino group, it has been reported ${ }^{31}$ that the $\mathrm{p} K_{\mathrm{a}}$ of deoxypolyoxamic acid is larger than that of polyoxamic acid by 0.3 . It has been also known that the $\mathrm{p} K_{\mathrm{a}}$ values of several amino acids are larger than those of their hydroxy analogues. ${ }^{12}$ ) The hydroxyl groups at $\mathrm{C}-3^{\prime \prime}$ and $\mathrm{C}-4{ }^{\prime \prime}$ is considered to lower $\mathrm{p} K_{\mathrm{a}}$ of the amino group at $\mathrm{C}-2$ ", so that the difference in the $\mathrm{pH}$ values for the bends described above is found. In any event, the ionized amino group at C-2" of polyoxins seems to contribute to form a bonding with an appropriate group, perhaps charged negatively, of the enzyme. And, as described previously, "since the exact position of this amino group is important for the binding of polyoxins to the enzyme, the above assumed group of the enzyme is seemed to have a specific position corresponding to the amino group.

The $\mathrm{pH}$ profile of the inhibitory activity of $\delta$-CAO-DL-norvalyl-TPoC shows more rapid fall with increasing of $\mathrm{pH}$ than that for $\mathrm{L}-$ norvalyl-TPoC over $\mathrm{pH}$ range $7.2 \sim 8.2$. $\delta$ CAO-DL-norvalyl-TPoC is an equivalent mixture contains each isomer at a concentration of $62.5 \mu \mathrm{g} / \mathrm{ml}$. At this concentration, the Disomer scarcely affects the enzyme. ${ }^{21}$ Therefore, it is suggested that the difference found in the two $\mathrm{pH}$ profiles presumably arises from the presence of carbamoyloxy group. The carbonyl oxygen atom of this group may participate in the hydrogen bond formation with an appropriate group, perhaps charged positively, of the enzyme.

The $\mathrm{p} K i$ - $\mathrm{pH}$ profile for uridine and for UMP have bends at $\mathrm{pH} 7.8$ and 8.0 , respectively. Neither of these compounds contain any dis- sociation group whose $\mathrm{p} K_{\mathrm{a}}$ is above the values. Therefore, the bends are possibly attributed to a change "in electrical charge of a dissociation group (e.g., an amino group) of the free enzyme and of the enzyme-inhibitor complex. Uridine, UMP and UDP-glucose competitively inhibit the enzyme, while little inhibition is observed by cytidine, CMP and CDP-glucose, which structures are very similar to their uridine counterparts, except oxygen atom at $\mathrm{C}-4$ position of uracil is substituted by amino group. ${ }^{1,2}$ These findings suggest that this amino group interferes with the interaction between the cytidine analogues and the binding site. Conversely, it is presumed that the oxygen atom at $\mathrm{C}-4$ participates in the uridinebinding site interaction. From the $\mathrm{pKm}$ - $\mathrm{pH}$ profile for UDP-GlcNAc, the $\mathrm{pKe}_{2}$ and the pKes 2 are found to be 7.7 and 8.0, respectively. An amino group is suppose as a dissociation group which shows such $\mathrm{pKe} e_{2}$ value. It is likely that a positively charged amino group of the binding site is concerned in the formation of hydrogen bonding with an appropriate atom, presumably the oxygen atom at $\mathrm{C}-4$, of the uridine moiety of UDP-GlcNAc. Thus the affinity of uridine to the enzyme is weakened with disappearance of the positive charge. The $-\Delta g$ for the hydroxyl group at $\mathrm{C}-2^{\prime}$ of the ribose moiety is approximately $1.0 \mathrm{kcal} /$ mol. ${ }^{2}$ This and another hydroxyl group at C -3 ' probably contribute to form the hydrogen bonding with relevant groups of the enzyme.

It has been described previously ${ }^{2}$ that the $-\Delta g$ for the phosphate group of UMP and for the pyrophosphate group of UDP are 0.1 and $0.2 \mathrm{kcal} / \mathrm{mol}$, respectively. The $\mathrm{p} K i-\mathrm{pH}$ curve for UMP shows, as compared with that for uridine, that the phosphate group is effective on the $K i$ of this compound over $\mathrm{pH}$ range $6.0 \sim 7.0$, and indicates the downward curvature near $\mathrm{pH}$ 6.7. While the $\mathrm{pKe} e_{1}$ and the $\mathrm{p} K e s_{1}$ found are about 6.3 and 6.0 , respectively. The imidazole group of a histidine residue has been known as a dissociation group having such $\mathrm{p} K e_{1}$ value. ${ }^{4)}$ And the imidazole group has been proposed as an essential part of the active site of various enzyme ${ }^{\beta)}$ such like $a$ - 
chymotrypsin,,$^{9 /}$ fumarase $\mathrm{e}^{(0)}$ and acetylcholinesterase. ${ }^{11}$ From these facts, it is concluded that an unprotonated imidazole group presumably interacts with the pyrophosphate moiety of UDP-GleNAc in the catalytic process of the enzyme. In the case of UMP, its free phosphate group may be bound to the same but positively charged imidazole group. That is to say, the former action is nucleophilic and the latter action is electrophilic.

The proposed mechanism of interaction
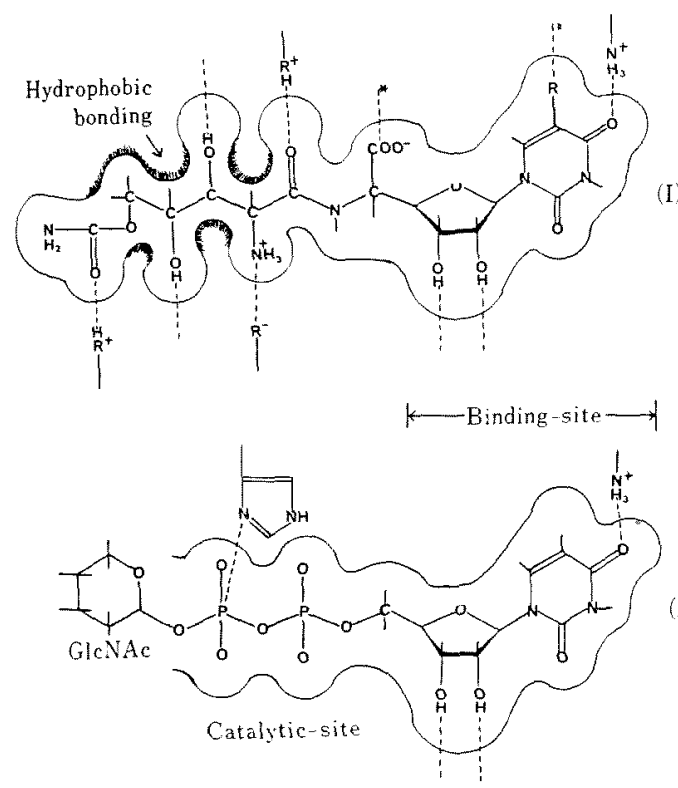

FIG. 7. Proposed Mechanism of Interaction between Polyoxin (I) or UDP-N-acetylglucosamine (II) and Active Center of Chitin Synthetase.

* The values of partial binding affinity for the $-\mathrm{COOH}$ and the $-\mathrm{R}\left(=\mathrm{CH}_{3}\right)$ groups are 0.7 and $0.4 \mathrm{kcal} / \mathrm{mole}$, respectively. ${ }^{2}$ ) between polyoxin or UDP-GICNAc and the active center of chitin synthetase is summarized in Fig. 7.

Acknowledgement. The authors wish to express their sincere thanks to Dr. Y. Sumiki, Emeritus Professor of Tokyo University, for his guidance and encouragement and Dr.S. Suzuki, the Institute of Physical and Chemical Research, for his valuable advice to this work.

\section{REFERENCES}

1) M. Hori, K. Kakiki, S. Suzuki and T. Misato, Agr. Biol. Chem., 35, 1280 (1971).

2) M. Hori, K. Kakiki and T. Misato, ibid., 38691 (1974).

3) K. Isono, K. Asahi and S. Suzuki, J. Amer. Chem. Soc., 91, 7490 (1969).

4) M. Dixon and E. C. Webb, "Enzymes," 2nd Ed., Longmans, London, 1964, p. 116.

5) K. Isono, S. Suzuki and T. Azuma, Agr. Biol. Chem., 35, 1986 (1971).

6) K. Isono, S. Suzuki, M. Tanaka, T. Nanbata and K. Shibuya, Tetrahedron, No. 6, 425 (1970).

7) H. Lineweaver and D. Burk, $J$, Amer. Chem. Soc. 56, 658 (1934).

8) E. Shaw, "The Enzymes," 3rd Ed., Vol. I, Academic Press Inc., New York, N. Y., 1971.

9) H. Gutfreund and J. M. Sturtevant, Biochem. J. (London), 63, 656 (1956).

10) V. Massey and R. A. Alberty, Biochim. Biophys. Acta, 13, 354 (1954); C. Frieden and R. A. Alberty J. Biol. Chem., 212, 859 (1955).

11) I. B. Wilson and F. Bergmann, ibid., 186, 683 (1950)

12) R. M. C. Dawson, D. C. Elliott, W. H. Elliott and K. M. Jones, "Data for Biochemical Research," 2nd Ed., Clarendon Press, Oxford, 1969, p. 1 . 